\title{
GS29696 - A NEW HERBICIDE FOR NON-SELECTIVE WEED CONTROL
}

\author{
T. M. PATTERSON \\ Ciba-Geigy New Zealand Limited, Cambridge
}

\author{
S. J. RAE \\ Ciba-Geigy New Zealand Limited, Christchurch
}

\begin{abstract}
Summary
A new urea derivative herbicide GS29696 was evaluated for nonselective weed control over a period of two years under diverse rainfall and soil conditions. GS29696 at $8 \mathrm{~kg} / \mathrm{ha}$ gave overall vegetation control and residual activity superior to bromacil, karbutilate and a proprietary simazine/2,2-DPA/amitrole mixture including the control of a number of common perennial weeds resistant to these standard treatments. Established paspalum was resistant to GS29696. GS29696 was more effective under moist soil and active growth conditions than during hot dry weather. Under very dry and very wet conditions, the addition of either paraquat or amitrole was beneficial.
\end{abstract}

\section{INTRODUCTION}

GS29696 is a new urea derivative with the chemical name 1,3-dimethyl1-(5-trifluoromethyl-1,3,4-thiadiazol-2-yl) urea. Technical details relating to this material are available on request. Since 1971 , the evaluation has been carried out in the Waikato (sandy clay loam complex soils with a mean annual rainfall of $125 \mathrm{~cm}$ ), Canterbury (silt loams and $65 \mathrm{~cm}$ rainfall) and westland (alluvial and $450 \mathrm{~cm}$ rainfall) areas. These provide a marked contrast in soil type and climate, as well as an extensive range of weeds which commonly occur in non-crop situations. Treatments were generally replicated and randomised and applied in 1500 to 2000 litres water/ha. All assessments were visual using the 1 to 9 EWRC scale of weed control ratings for the amount of bare ground present.

\section{RESULTS AND DISCUSSION}

Detailed assessments from only ten of the fifteen trials are shown in tables 1 and 2 , as two trials were prematurely destroyed and three specifically involve the control of paspalum (Paspalum dilatatum).

Rate of application

As shown in Table 1 , two initial trials on established vegetation showed GS29696 at $11 \mathrm{~kg} / \mathrm{ha}$ to be of much greater activity and persistence than other sterilant herbicides on a wide range of perennial broadleafs and grasses. Subsequent trials showed $8 \mathrm{~kg} / \mathrm{ha}$ to be an acceptable rate for both the spectrum and degree of weed control achieved and the length of residual activity. A slight increase in this rate would sometimes be required in the Waikato to achieve eradication of some clumpy type perennial grasses which tend to be more active in growth in the more northern region.

Time of application

Under cold moist conditions in Canterbury, application in June took between four and six months to achieve maximum effect, but only about three months when applied during warmer weather in October. However, 
New Products

TABLE 1: COMPARISON OF CHEMICALS FOR OVERALL VEGETATION CONTROL

(EWRC rating 1 to 9 )

\begin{tabular}{lcccc}
\hline \multicolumn{2}{l}{ Trial location } & Waikato & \multicolumn{2}{c}{ Canterbury } \\
\hline Treated & $25 / 5 / 71$ & \multicolumn{2}{c}{$10 / 6 / 71$} \\
\multicolumn{2}{l}{ Assessed (months) } & 6 & 6 & 12 \\
Cumulative rainfall $(\mathrm{cm})$ & 88 & 23 & 48 \\
Treatment & $(\mathrm{kg} / \mathrm{ha})$ & & & 1.5 \\
GS29696 & 5.5 & & 1.5 & 1.0 \\
GS29696 & 11 & 3.0 & 1.5 & 3.0 \\
bromacil & 11 & 9.0 & 3.5 & 8.0 \\
karbutilate & 11 & 9.0 & 3.0 & 6.5 \\
diuron & 11 & 8.0 & 6.0 & 8.0 \\
atrazine & 11 & 9.0 & 3.0 & \\
simazine & 11 & 9.0 & 6.5 & \\
\hline
\end{tabular}

in the Waikato where seasonal differences were not as great, applications in either May, September or October generally took six to eight weeks to achieve a similar result. Herbicidal activity was related to the growth phase of the vegetation and providing application was made prior to or at the onset of weed growth with moist conditions following, excellent results were achieved. This was demonstrated in trials 4 and 7 situated on fairly similar heavy silt loam sites in Canterbury, where the October application followed by a very dry and hot spring-summer period gave a much poorer overall result than one made four months earlier in trial 4. Sandy soil and restricted weed spectrum in trial 6 resulted in a superior result to trial 7 .

\section{Residual activity}

Under moist Waikato conditions, $8 \mathrm{~kg} / \mathrm{ha}$ GS29696 gave acceptable weed control for at least 12 months, while $4 \mathrm{~kg} / \mathrm{ha}$ lasted between six and nine months before seedlings became established. In comparison, either $8 \mathrm{~kg} / \mathrm{ha} \mathrm{karbutilate}$ or the commercial simazine/2,2-DPA/amitrole mixture was considerably less residual, lasting about six months. Under the drier Canterbury conditions, $8 \mathrm{~kg} / \mathrm{ha}$ GS29696 showed at least 15 months residual activity, but again the other materials, especially the simazine mixture, were less residual. Although the solubility of GS29696 in water is comparatively high (about $2500 \mathrm{ppm}$ ), overseas work indicates that its long residual effect is due to its adsorption to clay and organic colloids, with only a slow gradual desorption.

\section{Weed susceptibility}

The list of weed species present in the treated areas and their susceptibility to both 4 and $8 \mathrm{~kg} / \mathrm{ha}$ GS29696 is set out in Table 3 . The following comments on certain weed species relate to the overall ratings in Table 2.

Couch: In the Waikato, $8 \mathrm{~kg} / \mathrm{ha}$ GS29696 was superior to the other treatments, and gave excellent suppression of regrowth for at least 12 months. The $4 \mathrm{~kg} / \mathrm{ha}$ rate gave acceptable but not long-term control. Ineffective residual control of couch in the four Canterbury trials resulted in poorer ratings for the simazine/2,2-DPA/amitrole mixture.

Paspalum: Although seedlings less than $15 \mathrm{~cm}$ diam. were killed by $11 \mathrm{~kg} / \mathrm{ha}$, established plants were resistant to $17 \mathrm{~kg} / \mathrm{ha}$ of GS29696, showing only some temporary leaf chlorosis and growth check. 


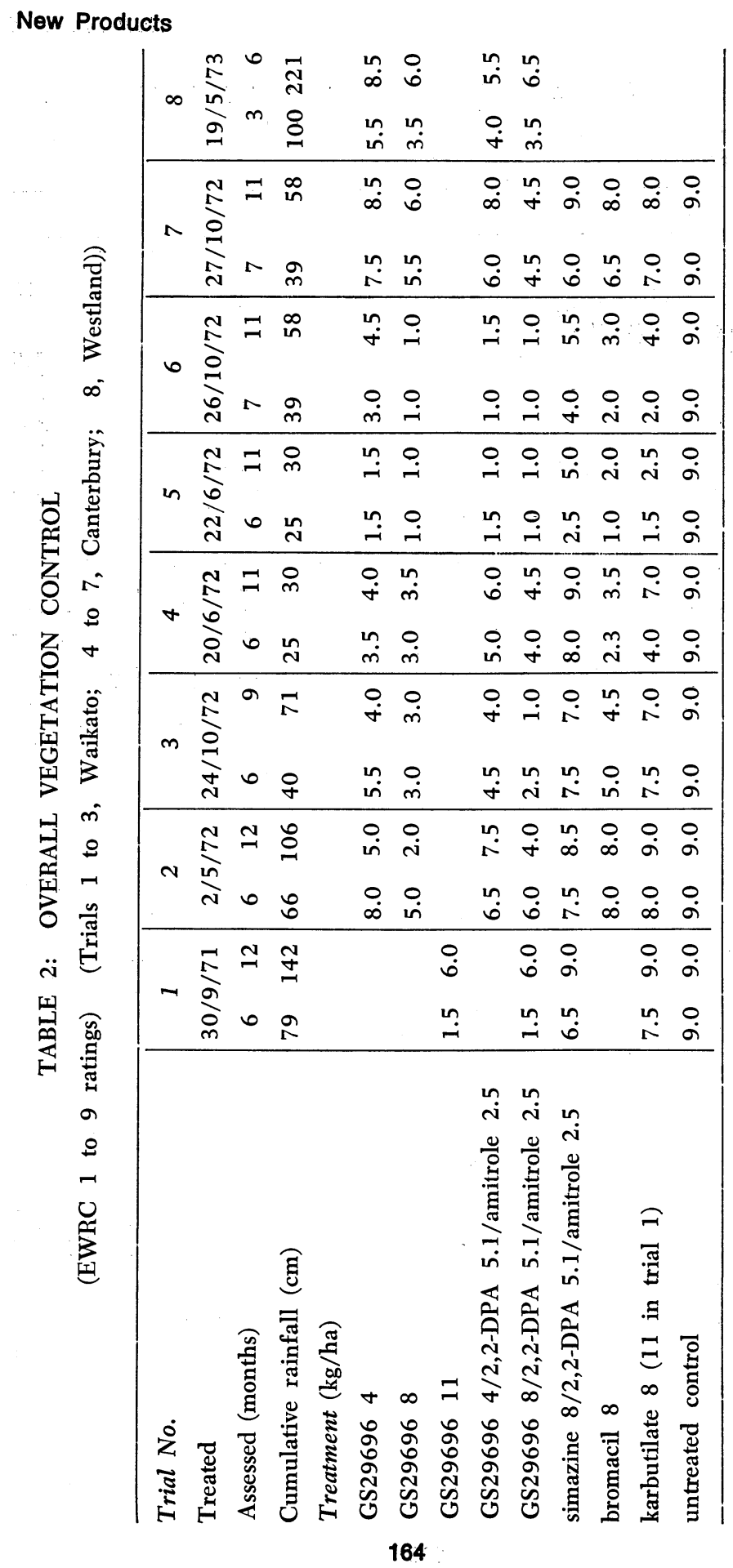


Greater bindweed: The poor overall control at six months in trial 2 is due to the considerable amount of greater bindweed present which was beginning to grow relatively uncontrolled on most treatments except $8 \mathrm{~kg} / \mathrm{ha}$ GS29696. Grazing subsequently reduced the infestation and this accounts for the increase in control at later assessments. GS29696 was the only chemical to give acceptable control, and compared with $8 \mathrm{~kg} / \mathrm{ha}$, the $4 \mathrm{~kg}$ rate was inadequate for long term control.

Seedling control: The residual effect of $8 \mathrm{~kg} / \mathrm{ha}$ GS29696 gave excellent control of a number of seedling weeds at the time when other materials were breaking down. These included such simazine resistant species as hemlock (Conium maculatum), wild carrot, Scotch thistle, crowfoot grass (Eleusine indica), summer grass (Digitaria sanguinalis); and karbutilate tolerant ones of fleabane, hawksbeard, catsear, dovesfoot, creeping buttercup, field speedwell (Veronica arvensis) and storksbill (Erodium spp.).

TABLE 3: EFFECT OF GS29696 ON WEED SPECIES AT 6 TO 9 MONTHS

\begin{tabular}{|c|c|c|}
\hline Established weed species & $\begin{array}{c}\text { Rates } \\
4\end{array}$ & $\underset{8}{\mathrm{~kg} / \mathrm{ha} a}$ \\
\hline bromus mollis (Bromus mollis) & $\mathbf{x x}$ & $x \mathbf{x}$ \\
\hline $\begin{array}{l}\text { cocksfoot (Dactylis glomerata) } \\
\text { couch (Agropyron repens) }\end{array}$ & & $\mathbf{x x}$ \\
\hline $\begin{array}{l}\text { couch (Agropyrom repens) } \\
\text { paspalum (Paspalum dilatatum) }\end{array}$ & $\mathbf{x}$ & $\mathbf{x} \mathbf{x}$ \\
\hline $\begin{array}{l}\text { paspalum (Paspalum dilatatum) } \\
\text { perennial ryegrass (Lolium perenne) }\end{array}$ & $\begin{array}{r}0 \\
\mathbf{x x}\end{array}$ & $\begin{array}{r}0 \\
\mathbf{x x}\end{array}$ \\
\hline $\begin{array}{l}\text { perennial ryegrass (Lolium perenne) } \\
\text { poa annua (Poa annua) }\end{array}$ & $\mathrm{xx}$ & $\begin{array}{l}\mathbf{x x} \\
\mathbf{x x}\end{array}$ \\
\hline praire grass (Bromus unioloides) & $\mathbf{x}$ & $\begin{array}{c}x x \\
x x\end{array}$ \\
\hline ripgut brome (Bromus diandrus) & $\mathbf{x x}$ & $\mathbf{x x}$ \\
\hline sweet vernal (Anthoxanthum odoratum) & $\mathbf{x x}$ & $\mathbf{x x}$ \\
\hline tall fescue (Festuca arundinacea) & o & $\mathbf{x x}$ \\
\hline Yorkshire fog (Holcus lanatus) & $\mathbf{x x}$ & $\mathbf{x x}$ \\
\hline catsear (Hypochaeris radicata) & $\mathbf{x x}$ & $\mathbf{x x}$ \\
\hline cleavers (Galium aparine) & o & $\mathbf{x x}$ \\
\hline creeping buttercup (Ranunculus repens) & o & $\mathbf{x x}$ \\
\hline creeping mallow (Modiola caroliniana) & o & $\mathbf{o}$ \\
\hline dandelion (Taraxacum officinale) & $\mathbf{x}$ & $\mathbf{x x}$ \\
\hline docks (Rumex spp.) & o & $\mathbf{x x}$ \\
\hline dovesfoot (Geranium molle) & $\mathbf{x x}$ & $\mathbf{x x}$ \\
\hline fireweed (Erechtites spp.) & $\mathbf{x x}$ & $\mathbf{x x}$ \\
\hline fleabane (Erigeron spp.) & $\mathrm{xx}$ & $\mathbf{x x}$ \\
\hline greater bindweed (Ĉalystegia sepium) & o & $\mathbf{x}$ \\
\hline hawksbeard (Crepis capillaris) & $\mathrm{xx}$ & $\mathbf{x x}$ \\
\hline lotus major (Lotus pedunculatus) & $\mathrm{xx}$ & $\mathbf{x} \mathbf{x}$ \\
\hline mint (Mentha spp.) & ( ) & $\mathbf{x x}$ \\
\hline narrow-leaved plantain (Plantago lanceolata) & $\mathbf{o}$ & $\mathbf{x}$ \\
\hline prostrate amaranth (Amaranthus deflexus) & $\mathbf{o}$ & $\mathbf{o}$ \\
\hline red clover (Trifolium pratense) & $\mathbf{x x}$ & $\mathbf{x x}$ \\
\hline Scotch thistle (Cirsium vulgare) & $x^{x x}$ & $\mathbf{x x}$ \\
\hline Spanish heath (Erica lusitanica) & ( ) & $\mathbf{x x}$ \\
\hline white clover (Trifolium repens) & $\mathbf{X x}$ & $\mathbf{x x}$ \\
\hline wild & $\mathbf{x}$ & $\mathbf{X X}$ \\
\hline yarrow & $\mathbf{x x}$ & $\mathbf{x x}$ \\
\hline
\end{tabular}

yarrow (Achillea millefolium)

$\begin{array}{ccc} & \text { EWRC Control Ratings } \\ \mathbf{x x}=\text { excellent control/kill } & 1-2 & (98-100 \%) \\ \mathbf{x}=\text { acceptable control } & 3-5 & (85-95 \%) \\ \mathbf{0}=\text { unacceptable control } & 6-9 & (0-72 \%)\end{array}$

0 = unacceptable control

) $\overline{\bar{G}}$ insufficient data

* $\mathrm{\overline {G }} 29696$ (4 kg/ha) gave acceptable control in Canterbury but was unacceptable in Waikato. 


\section{New Products}

\section{Herbicide mixtures}

In general the overall degree of control from $8 \mathrm{~kg} / \mathrm{ha}$ GS29696 on a wide range of broadleaf and grass weed species was such that it did not require specific additional herbicides. However, in paspalum dominant situations, the use of karbutilate was necessary to achieve acceptable control and the addition of $4 \mathrm{~kg} / \mathrm{ha}$ GS29696 was beneficial in extending herbicidal activity in the soil as well as severely checking a number of perennial broadleafs and grasses previously shown by Palmer et al (1972) to be tolerant of karbutilate. The activity of GS29696 through the roots was generally sufficient to give excellent control, except under dry soil conditions, in which case the addition of foliar acting herbicides was beneficial. GS29696 was often slow acting and the addition of either $0.9 \mathrm{~kg} / \mathrm{ha}$ paraquat or $3 \mathrm{~kg} / \mathrm{ha}$ amitrole, greatly increased the speed of knockdown of perennial grasses and broad-leaved weeds respectively. In trial 8, excellent and rapid control of perennial grasses was achieved by the addition of paraquat to GS29696, and this mixture provided a reasonable period of vegetation control in view of the considerably shorter period of residual activity under the high rainfall conditions.

\section{CONCLUSIONS}

1. In an evaluation extending over two years, limited mainly to the Waikato and Canterbury regions, the new non-selective soil acting herbicide GS29696, gave control of a greater number of annual and perennial broadleaf weeds and grasses, and longer term residual activity in the soil than other currently available materials.

2. Established paspalum is resistant.

3. The speed of knockdown can be increased by the addition of either paraquat or amitrole.

\section{ACKNOWLEDGEMENTS}

To the various personnel in Local Bodies, Ministry of Works, and N.Z. Railways for the provision of trial sites.

\section{REFERENCE}

Palmer, P. C., Mackay, A. G. and O'Connor, B. P., 1972. Non-selective vegetation control with karbutilate. Proc. 25th N.Z. Weed \& Pest Control Conf.: 76.

Proc. 27th N.Z. Weed and Pest Control Conf. 